\title{
EGU2013 SM1.4/GI1.6 session: "Improving seismic networks performances: from site selection to data integration"
}

\author{
D. Pesaresi ${ }^{1,2}$ and R. Busby ${ }^{3}$ \\ ${ }^{1}$ OGS (Istituto Nazionale di Oceanografia e di Geofisica Sperimentale), Trieste, Italy \\ ${ }^{2}$ Istituto Nazionale di Geofisica e Vulcanologia, Roma, Italy \\ ${ }^{3}$ Incorporated Research Institutions for Seismology, Washington, USA
}

Correspondence to: D. Pesaresi (dpesaresi@inogs.it)

\begin{abstract}
The number and quality of seismic stations and networks in Europe continually improves, nevertheless there is always scope to optimize their performance. In this session we welcomed contributions from all aspects of seismic network installation, operation and management. This includes site selection; equipment testing and installation; planning and implementing communication paths; policies for redundancy in data acquisition, processing and archiving; and integration of different datasets including GPS and OBS.
\end{abstract}

\section{Introduction}

The history of seismic network sessions at European Geosciences Union (EGU) General Assemblies starts in 2010 with the SM1.3 "Seismic Centers Data Acquisition" session (Pesaresi, 2011 and EGU2010 SM1.3 Seismic Centers Data Acquisition, 2010), where the Convener Damiano Pesaresi supported by the Orfeus Data Center Director CoConvener Reinoud Sleeman chaired a session of 7 oral and 16 posters. A similar session was later the same year held at the XXXII European Seismological Commission (ESC) General Assembly: "SD1, 3 Seismic centers data acquisition", conveners D. Pesaresi and R. Sleeman, with 15 oral presentations.

The history continues in 2011 with the EGU2011 SM1.3/G3.8/GD3.7/GI-19/TS8.7 "Improving seismic networks performances: from site selection to data integration" session (EGU2011 SM1.3/G3.8/GD3.7/GI-19/TS8.7 Improving seismic networks performances: from site selection to data integration, 2011) where the Convener Damiano Pesaresi supported by the Co-Conveners John Clinton and Robert Busby chaired a session of 9 oral and 20 posters and in 2012 with the EGU2012 SM1.3/GI1.7 "Im- proving seismic networks performances: from site selection to data integration" session (Pesaresi and Vernon, 2013 and EGU2012 SM1.3/GI1.7 Improving seismic networks performances: from site selection to data integration, 2012) where the Convener Damiano Pesaresi supported by the CoConvener Frank Vernon chaired a session of 6 oral and 22 posters.

\section{The EGU2013 SM1.4/GI1.6 session}

In the EGU2013 SM1.4/GI1.6 "Improving seismic networks performances: from site selection to data integration" session (EGU2013 SM1.4/GI1.6 Improving seismic networks performances: from site selection to data integration, 2013) the Convener Damiano Pesaresi supported by the Co-Convener Robert Busby chaired a session (Fig. 1) of 6 oral (Table 1) and 13 posters (Table 2 ).

The 19 presentations comes from 9 countries (France, Switzerland, Italy, Portugal, USA, Austria, Bulgaria, Algeria, Greece) from 3 different continents (North America, Europe, and Africa), which well fits the goals of the European Geosciences Union.

Presentations worth mentioning in this session were:

1. "Site selection for the future stations of the French permanent broadband network" by J. Vergne, O. Charade and the RESIF-CLB Team (Vergne et al., 2013), which showed the re-organization and modernization of the French seismic network with new standards for installations;

2. "SalanderMaps: A rapid overview about felt earthquakes through data mining of web-accesses" by U. Kradolfer (Kradolfer, 2013), a very interesting presentation that showed how it is possible to get a rapid 
Table 1. Oral Programme EGU2013 SM1.4/GI1.6 session.

\begin{tabular}{|c|c|c|}
\hline EGU Abstract ref. & Title & Authors \\
\hline EGU2013-4305 & $\begin{array}{l}\text { Site selection for the future stations of the } \\
\text { French permanent broadband network }\end{array}$ & $\begin{array}{l}\text { Jérôme Vergne, Olivier Charade and the RESIF- } \\
\text { CLB Team }\end{array}$ \\
\hline EGU2013-6400 & $\begin{array}{l}\text { SalanderMaps: A rapid overview about felt } \\
\text { earthquakes through data mining of web- } \\
\text { accesses }\end{array}$ & Urs Kradolfer \\
\hline EGU2013-7166 & $\begin{array}{l}\text { OGS improvements in } 2012 \text { in running the } \\
\text { Northeastern Italy Seismic Network: the Fer- } \\
\text { rara VBB borehole seismic station }\end{array}$ & $\begin{array}{l}\text { Damiano Pesaresi, Marco Romanelli, Carla } \\
\text { Barnaba, Pier Luigi Bragato, and Giorgio Durì }\end{array}$ \\
\hline EGU2013-7496 & $\begin{array}{l}\text { Ambient noise recorded at broadband stations } \\
\text { in Portugal and Morocco: Characterization and } \\
\text { Sources }\end{array}$ & $\begin{array}{l}\text { Susana Custódio, Guilherme Madureira, Carlos } \\
\text { Corela, Paulo Alves, Christian Haberland, Fer- } \\
\text { nando Carrilho, Joao Fonseca, Bento Caldeira, } \\
\text { Nuno Dias and the WILAS Team }\end{array}$ \\
\hline EGU2013-9072 & $\begin{array}{l}\text { Strategy for the deployment of a dense broad- } \\
\text { band temporary array in the Alps: lessons learnt } \\
\text { from the CIFALPS experiment }\end{array}$ & $\begin{array}{l}\text { Aubert Coralie, Paul Anne, Solarino Stefano, } \\
\text { Roussel Sandrine, Salimbeni Simone, Zangelmi } \\
\text { Pierre, Cougoulat Glenn, Ai Yinshuang, Xu } \\
\text { Weiwei, He Yumei, and Zhao Liang }\end{array}$ \\
\hline EGU2013-13298 & $\begin{array}{l}\text { Sensor Emplacement Techniques and Seismic } \\
\text { Noise Analysis for USArray Transportable Ar- } \\
\text { ray Seismic Stations }\end{array}$ & $\begin{array}{l}\text { Robert Busby, Andy Frassetto, Katrin Hafner, } \\
\text { Robert Woodward, and Allan Sauter }\end{array}$ \\
\hline
\end{tabular}

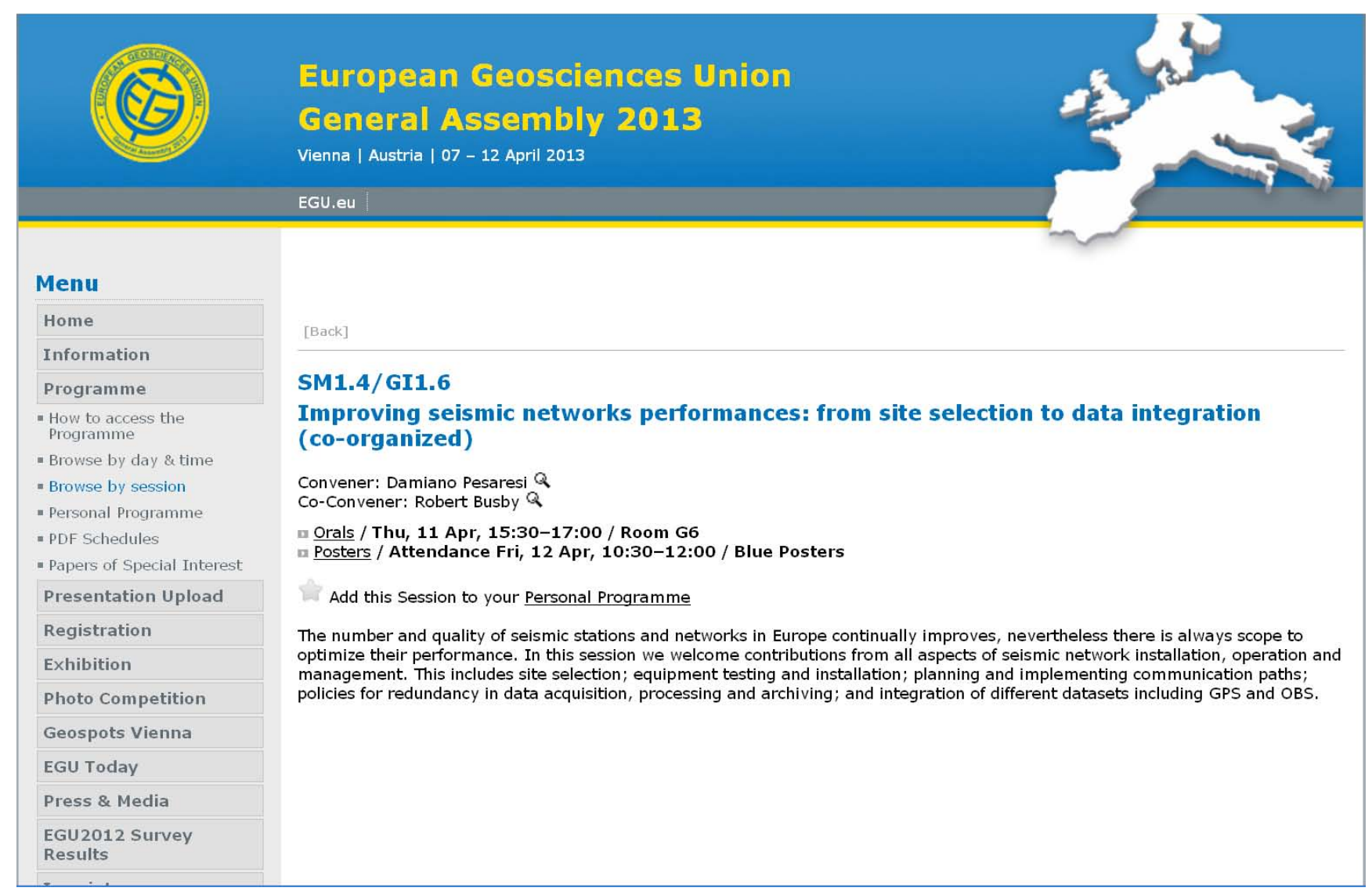

Fig. 1. EGU2013 SM1.4/GI1.6 session (from EGU2013 Homepage). 
Table 2. Poster Programme EGU2013 SM1.4/GI1.6 session.

\begin{tabular}{|c|c|c|}
\hline EGU Abstract ref. & Title & Authors \\
\hline EGU2013-3837 & $\begin{array}{l}\text { Improving Seismic Monitoring in Northern } \\
\text { Switzerland }\end{array}$ & $\begin{array}{l}\text { Katrin Plenkers, Stephan Husen, and Michael } \\
\text { Schnellmann }\end{array}$ \\
\hline EGU2013-4532 & $\begin{array}{l}\text { Instrument Self-Noise and Sensor Misalign- } \\
\text { ment }\end{array}$ & Andreas Gerner and Götz Bokelmann \\
\hline EGU2013-5283 & $\begin{array}{l}\text { Automatic pickers performances in the case of } \\
\text { the Emilia sequence of May-June } 2012\end{array}$ & $\begin{array}{l}\text { Lara Tiberi, Daniele Spallarossa, and Giovanni } \\
\text { Costa }\end{array}$ \\
\hline EGU2013-6491 & $\begin{array}{l}\text { Acquisition Hardware for Rapid Seismic Event } \\
\text { Notification System }\end{array}$ & $\begin{array}{l}\text { Leonid Zimakov, Paul Passmore, Phil David- } \\
\text { son, and Tom Drake }\end{array}$ \\
\hline EGU2013-6985 & $\begin{array}{l}\text { Identification of response and timing issues at } \\
\text { permanent European broadband stations from } \\
\text { automated data analysis }\end{array}$ & $\begin{array}{l}\text { hristian Weidle, Riaz Ahmed Soomro, Luigia } \\
\text { Cristiano, and Thomas Meier }\end{array}$ \\
\hline EGU2013-7343 & $\begin{array}{l}\text { The Interreg IV Italia-Austria "SeismoSAT" } \\
\text { Project: connecting Seismic Data Centers via } \\
\text { satellite }\end{array}$ & $\begin{array}{l}\text { Damiano Pesaresi, Wolfgang Lenhardt, Markus } \\
\text { Rauch, Mladen Zivcic, Rudolf Steiner, Paolo } \\
\text { Fabris, and Michele Bertoni }\end{array}$ \\
\hline EGU2013-7423 & A multiple-criteria network optimization & $\begin{array}{l}\text { Anna Tramelli, Giuseppe De Natale, Claudia } \\
\text { Troise, and Massimo Orazi }\end{array}$ \\
\hline EGU2013-7906 & $\begin{array}{l}\text { Extending a Lippmann style seismometer's dy- } \\
\text { namic range by using a non-linear feedback cir- } \\
\text { cuit }\end{array}$ & Giovanni Romeo and Giuseppe Spinelli \\
\hline EGU2013-9486 & $\begin{array}{l}\text { System of Earthquakes Alert (SEA) on the } \\
\text { territory of Bulgaria developed as a result of } \\
\text { DACEA project }\end{array}$ & $\begin{array}{l}\text { Dimcho Solakov, Liliya Dimitrova, Stela Sime- } \\
\text { onova, Irena Aleksandrova, Stoyan Stoyanov, } \\
\text { and Metodi Metodiev }\end{array}$ \\
\hline EGU2013-9828 & $\begin{array}{l}\text { The Algerian Seismic Network: Performance } \\
\text { from data quality analysis }\end{array}$ & $\begin{array}{l}\text { Abdelkarim Yelles, Toufik Allili, and Azouaou } \\
\text { Alili }\end{array}$ \\
\hline EGU2013-10783 & $\begin{array}{l}\text { Evolution and strengthening of the Calabrian } \\
\text { Regional Seismic Network during the Pollino } \\
\text { sequence }\end{array}$ & $\begin{array}{l}\text { Antonino D'Alessandro, Anna Gervasi, and Ig- } \\
\text { nazio Guerra }\end{array}$ \\
\hline EGU2013-10994 & $\begin{array}{l}\text { Planning the improvement of seismic monitor- } \\
\text { ing in a volcanic supersite: experience on Mt. } \\
\text { Etna }\end{array}$ & $\begin{array}{l}\text { Antonino D'Alessandro, Luciano Scarfi, Anto- } \\
\text { nio Scaltrito, Giampiero Aiesi, Sergio Di Prima, } \\
\text { Ferruccio Ferrari, and Salvatore Rapisarda }\end{array}$ \\
\hline EGU2013-12634 & $\begin{array}{l}\text { Operational network improvements and in- } \\
\text { creased reporting in the NOA (Greece) seismic- } \\
\text { ity catalog }\end{array}$ & $\begin{array}{l}\text { Gerasimos Chouliaras, Nikolaos Melis, Geor- } \\
\text { gios Drakatos, and Konstantinos Makropoulos }\end{array}$ \\
\hline
\end{tabular}

rough earthquake location by simply checking anomalous internet connections to seismic information web pages;

3. "Strategy for the deployment of a dense broadband temporary array in the Alps: lessons learnt from the CIFALPS experiment" by C. Aubert, A. Paul, S. Solarino, S. Roussel, S. Salimbeni, P. Zangelmi, G. Cougoulat, Y. Ai, W. Xu, Y. He, and L. Zhao (Aubert et al., 2013), which showed the very valuable practical experience coming from the installation and operation of the CIFALPS experiment;
4. "Sensor Emplacement Techniques and Seismic Noise Analysis for USArray Transportable Array Seismic Stations" by R. Busby, A. Frassetto, K. Hafner, R. Woodward, and A. Sauter (Busby et al., 2013), which showed best practice and future standard for seismic installations of the USArray project;

5. "The Algerian Seismic Network: Performance from data quality analysis" by A. Yelles, T. Allili, and A. Alili (Yelles et al., 2013), which showed impressive improvements in the seismic networks in North Africa.

The papers published in these proceedings of the EGU2012 SM1.3/GI1.7 session are: 
1. "Operational network improvements and increased reporting in the NOA (Greece) seismicity catalog" by G. Chouliaras, N. Melis, G. Drakatos, and K. Makropoulos, which shows the operation of the Greek seismic network;

2. "Extending a Lippmann style seismometer's dynamic range by using a non-linear feedback circuit" by G. Romeo and G. Spinelli, which shows how to extend electronically the capabilities of a classic seismic sensor;

3. "The new Algerian Digital Seismic Network (ADSN): Towards an early warning system" by A. YellesChaouche, T. Allili, A. Alili, W. Messemen, H. Beldjoudi, F. Semmane, A. Kherroubi, H. Djellit, Y. Larbes, S. Haned, and C. Nait Sidi Said, which shows the upgrades ind improvements of the Algerian National Seismic Network;

4. "Evolution and strengthening of the Calabrian Regional Seismic Network" by A. D'Alessandro, A. Gervasi, and I. Guerra, which shows improvements of seismic monitoring in the South of Italy in a very active area;

5. "Testing and optimization of the seismic networks of Campi Flegrei (Southern Italy)" by A. Tramelli, C. Troise, G. De Natale, and M. Orazi, which again shows improvements and testing in seismic networks in the South of Italy;

6. "Planning the improvement of seismic monitoring in a volcanic supersite: experience on Mt. Etna" by A. D'Alessandro, L. Scarfì, A. Scaltrito, S. Di Prima, and S. Rapisarda, which shows seismic monitoring of volcanoes techniques;

7. "Identification of response and timing issues at permanent European broadband stations from automated data analysis" by C. Weidle, R. A. Soomro, L. Cristiano, and T. Meier, which shows an interesting tool of seismic networks analysis;

8. "Instrument Self-Noise and Sensor Misalignment" by A. Gerner and G. Bokelmann, which shows a very useful software tool to check seismic sensors noise and installation;

9. "OGS improvements in 2012 in running the Northeastern Italy Seismic Network: the Ferrara VBB borehole seismic station" by D. Pesaresi, M. Romanelli, C. Barnaba, P. L. Bragato, and G. Durì, which shows the installation of a very broad band seismic station in a 130 meter deep borehole in Central Italy;

10. "The Interreg IV Italia-Austria "SeismoSAT" Project: connecting Seismic Data Centers via Satellite" by
D. Pesaresi, W. Lenhardt, M. Rauch, M. Zivčic, R. Steiner, P. Fabris and M. Bertoni, which shows how to connect seismic data canters via satellite;

11. "Sensor Emplacement Techniques and Seismic Noise Analysis for USArray Transportable Array Seismic Stations" by R. Busby, A. Frassetto, K. Hafner, R. Woodward, and A. Sauter, which shows the very valuable experience of USArray in installing semipermanent seismic stations.

\section{Conclusions}

The quality and quantity of presentations made at the EGU2013 SM1.4/GI1.6 session well satisfied the expectations of the Convener and Co-Convener, and well fitted the goals of the European Geosciences Union.

The steady number of presentation at such yearly seismic networks sessions encourage the conveners that the path they followed in organizing such sessions is a valid one, and that there is need in the seismological community worldwide to present and discuss different solutions to common problems in running seismic networks.

Acknowledgements. The authors thank the authors of the EGU2013 SM1.4/GI1.6 session presentations, especially those who made the effort to publish their presentations in these proceedings on Advances in Geosciences: J. Vergne, D. Pesaresi, R. Busby, A. Gerner, C. Weidle, A. Tramelli, G. Romeo, A. Alili, A. D'Alessandro and G. Chouliaras.

\section{References}

EGU2010 SM1.3 Seismic Centers Data Acquisition, http: //meetingorganizer.copernicus.org/EGU2010/session/2427 (last access: 26 March 2013), 2010.

EGU2011 SM1.3/G3.8/GD3.7/GI-19/TS8.7 Improving seismic networks performances: from site selection to data integration, http: //meetingorganizer.copernicus.org/EGU2011/session/7340 (last access: 26 March 2013), 2011.

EGU2012 SM1.3/GI1.7 Improving seismic networks performances: from site selection to data integration, http://meetingorganizer. copernicus.org/EGU2012/session/10081 (last access: 26 March 2013), 2012.

EGU2013 SM1.4/GI1.6 Improving seismic networks performances: from site selection to data integration, http://meetingorganizer copernicus.org/EGU2013/session/12573 (last access: 9 July 2013), 2013.

Aubert, C., Paul, A., Solarino, S., Roussel, S., Salimbeni, S., Zangelmi, P., Cougoulat, G., Ai, Y., Xu, W., He, Y., and Zhao, L.: Strategy for the deployment of a dense broadband temporary array in the Alps: lessons learnt from the CIFALPS experiment, EGU General Assembly, Vienna, Austria, 7-12 April 2013, EGU2013-9072, 2013.

Busby, R., Frassetto, A., Hafner, K., Woodward, R., and Sauter, A.: Sensor Emplacement Techniques and Seismic Noise Analysis for 
USArray Transportable Array Seismic Stations, EGU General Assembly, Vienna, Austria, 7-12 April 2013, EGU2013-13298, 2013.

Kradolfer, U.: SalanderMaps: A rapid overview about felt earthquakes through data mining of web-accesses, EGU General Assembly, Vienna, Austria, 7-12 April 2013, EGU2013-6400, 2013.

Pesaresi, D.: The EGU2010 SM1.3 Seismic Centers Data Acquisition session: an introduction to Antelope, EarthWorm and SeisComP, and their use around the World, Annals of Geophysics, 54, 1-7, doi:10.4401/ag-4972, 2011.
Pesaresi, D. and Vernon, F.: EGU2012 SM1.3/GI1.7 session: "Improving seismic networks performances: from site selection to data integration", Adv. Geosci., 34, 1-4, doi:10.5194/adgeo-341-2013, 2013.

Vergne, J., Charade, O., and the RESIF-CLB Team: Site selection for the future stations of the French permanent broadband network, EGU General Assembly, Vienna, Austria, 7-12 April 2013, EGU2013-4305, 2013.

Yelles, A., Allili, T., and Alili, A.: The Algerian Seismic Network: Performance from data quality analysis, EGU General Assembly, Vienna, Austria, 7-12 April 2013, EGU2013-9828, 2013. 